\title{
'Every Comfort of a Civilized Life': Interracial Marriage and Mixed Race Respectability in Southern New Zealand
}

\section{KATE STEVENS}

During his 1843 trip along the southern coast of New Zealand, government official Edward Shortland found the whaling settlement recently established at Jacob's River/Aparima (now Riverton) in the Foveaux Strait 'built on the southern slope of some well wooded hills, and being white-washed, and having near them green enclosures of corn and potatos, presented, while shone on by the morning sun, the most smiling and refreshing aspect imaginable'. Shortland's account presents a sharp contrast to descriptions of northern settlements in the Bay of Islands, where early cultural exchanges were often characterized by licentious and lewd behaviour. ${ }^{2}$ In the 1840 s, the population of Jacob's River/Aparima comprised a small but diverse group of European, Australian and American shore whalers and their Kāi Tahu wives and families. Most prominent among them was John Howell, the station manager and his young mixed race wife Caroline/Koronaki (née Brown), whose household formed the heart of the community. Given the disorderly reputation of whalers and the infancy of the Jacob's River settlement, it was with some surprise that local missionary Frederick Johannes Wohlers reported that he found 'every comfort of civilized life' while visiting the Howell household in $1846 .^{3}$

The Reverend Wohlers cut an unusual and striking figure amongst the rugged coastline of Foveaux Strait in the mid-nineteenth century. He had arrived in 1844 as the first missionary to the region, and he would remain there based at the island of Ruapuke for over 40 years until his death in 1885 . The surviving photographs depict him austerely attired in black missionary robes, an image that is hard to reconcile with the popular image of rough and ready whaling and sealing communities of the era. As an employee of the North German Missionary Society of Bremen, Wohlers was perhaps a surprising candidate to establish a mission in Foveaux Strait. Although Wohlers was suitably located for proselytizing to the indigenous population at the 'gathering place' of southern Kāi Tahu, he found himself very much isolated from the European society he knew. ${ }^{4}$ Upon arrival he barely spoke English, let alone Māori, which remained the lingua franca of the region in subsequent decades. His frequent reports to the mission authorities relay the difficulties and discomforts of everyday life in Ruapuke. It was little wonder he expressed delight at the comforts and hospitality he encountered in the home of Howell and his wife, which he frequented regularly while travelling the southern coast on his missionary circuit. ${ }^{5}$

This essay explores the emergence of the Howell family as social and economic leaders amongst the developing colonial settlement and pastoral economy in the nineteenth century, at a time when many mixed race families found themselves increasingly marginalized as the earlier resource-based economy declined. ${ }^{6}$ In particular, it explores how marriage underpinned the Howell family's prominence in the region, fashioning a set of kin relationships that must be understood in the context of the mixed race community that preceded colonial expansion. It moves beyond the scholarly focus on early interracial contacts, particularly on interracial sexual encounters, to look at the ways in which mixed raced families like the Howells successfully managed to live 'in-between worlds', making the transition from leading members of a mixed community that arose out of resource-based economics to colonial gentry. ${ }^{7}$ This was a shift inextricably linked to pastoralism, for it was primarily enterprising men, often of humble of origins, who established themselves as 
the emerging elite during the early colonial period through the astute use of capital, land, and family networks. ${ }^{8}$ While kinship connections within both the Kāi Tahu and European community underwrote the Howell's economic prosperity, social respectability and cultural capital in the form of education, housing and religion were equally significant to the establishment and maintenance of social status within the emerging colonial society.

I focus on the southern reaches of New Zealand because sustained interaction between local Kāi Tahu and newcomers had begun earlier and continued longer around Foveaux Strait and Stewart Island/Rakiura than elsewhere in New Zealand. The earliest partnerships of Māori women and newcomers began in the 1820s at the sealing settlement established at Codfish Island/Whenua Hou, where a small number of sealers from the Australian colonies settled with their Māori wives. A pattern of interracial interaction increased with the advent of shore-based whaling at Preservation Inlet in 1829 and the establishment of further coastal whaling stations along the southern and eastern coasts of Southland and Otago in subsequent decades. By 1844 New Zealand Company surveyor Frederick Tuckett estimated that from Banks Peninsula to Riverton 'two-thirds of the native women, who are not aged, are living with Europeans'. ${ }^{9}$ By $186468 \%$ of the Foveaux Strait population was of mixed ancestry. ${ }^{10}$ Throughout the period (1861-1921) in which censuses were taken recording the 'half-caste' population, mixed race individuals across the North Island never consisted of more than around $14 \%$ of the population. ${ }^{11}$ The dynamics of interracial marriage in the South Island were significantly different from those in the North Island at the same time. This difference can be attributed both to the smaller size of Kāi Tahu population, and to the nature of early European economic activity in southern New Zealand (sealing and whaling) which involved prolonged interaction with the local population and both temporary and permanent settlement along the southern coasts. ${ }^{12}$

Apart from their statistical significance in southern New Zealand, we need to pay attention to the lives of mixed race individuals because they offer an alternative means of interpreting race relations. Since 1985, when the Waitangi Tribunal was granted the power to investigate historical grievances relating to breaches of the Treaty of Waitangi, the history of Māori-Pākehā interactions has been written within the framework of treaty claims. This 'treaty straightjacket' has lead to a disproportionate focus on narratives of economic dispossession and social and political marginalization. ${ }^{13}$ Histories of Kāi Tahu are characterized by themes of dispossession and loss, and conversely of resistance and survival, which centre on struggles to maintain land and mahika kai (food resources) in the face of colonization and expanding agricultural settlement. The long struggle for compensation and redress through a process known as The Claim (Te Kerēme) figures prominently in these histories. ${ }^{14}$ Although undeniably a significant part of Kāi Tahu history, the history of Te Kerēme does not embody the totality of the Kāi Tahu experience, which included such 'exceptions to colonial rule' as tîtī harvesting, as well as more intimate encounters of colonialism such as interracial marriage. ${ }^{15}$ While the work of $\mathrm{Te}$ Kerēme and the Tribunal has been crucial in redressing historical injustices, histories of interracial marriage and mixed race families in New Zealand represent a fruitful area of research that incorporates a wider variety of social, cultural, economic and political issues than are examined in the context of treaty claims. Studies centred on kinship help us to think, in the words of Tony Ballantyne, 'under the nation' and force us to reconceptualize how race played out differently at specific times and in particular places. ${ }^{16}$ 


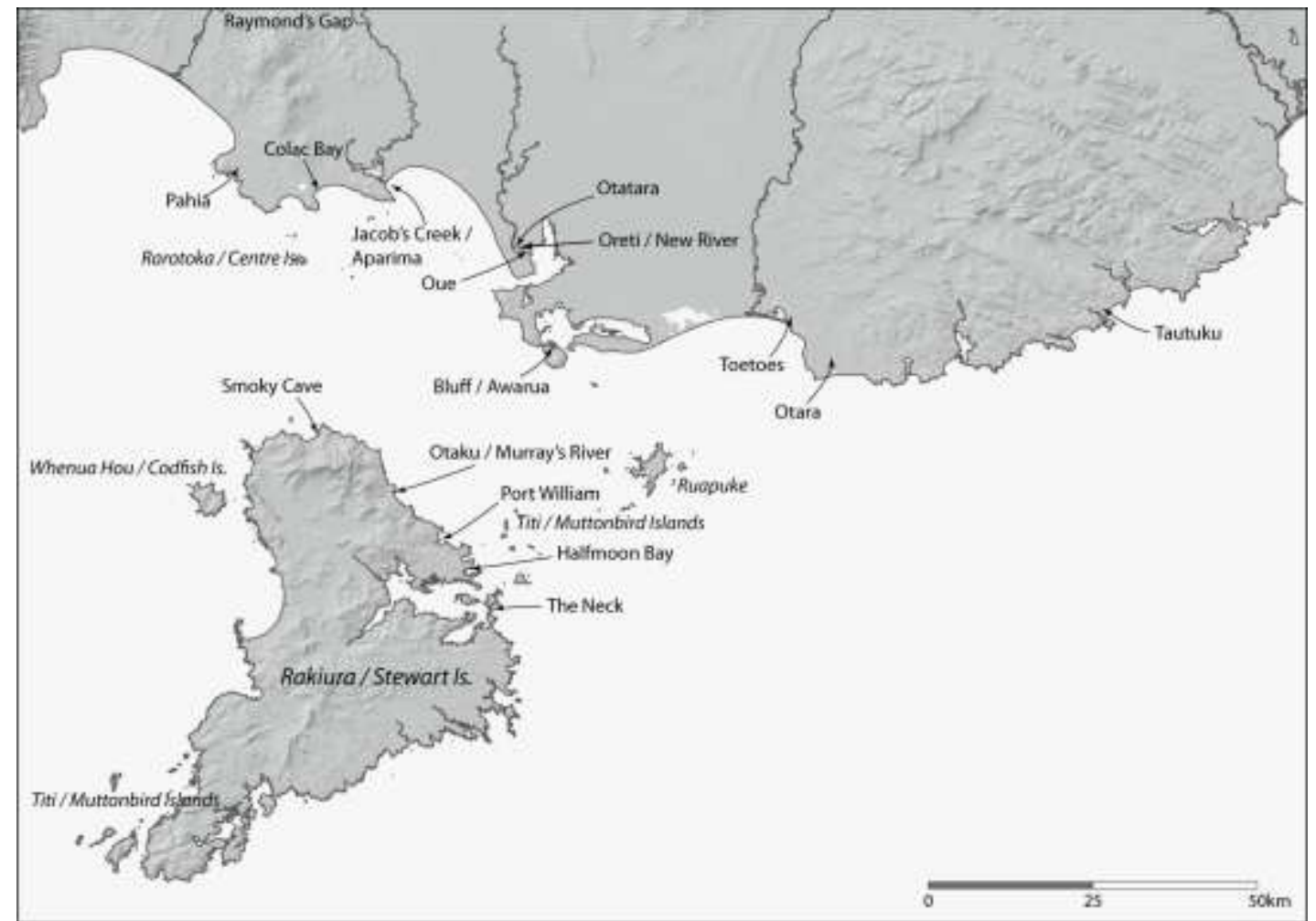

Figure 1: Location of the main mixed race settlements in the Foveaux Strait region.

\section{The importance of marriage}

In local histories, the Howells are described as the founding family of the Riverton community, then known as Jacob's River or Aparima. The Howells have left a substantial imprint on the historical record in the form of land claims, probates, family memories and contemporaneous observations by visiting missionaries and government officials. ${ }^{17}$ It is therefore possible to reconstruct aspects of the historical experience of this family in reasonable detail. As will be seen, their optimistic portrayal as early colonists and pioneers by local historians overshadows the more complex and ambivalent experience of racial hybridity in colonial New Zealand as well as their significant and enduring engagements with Māori or mixed race women, or the Kāi Tahu community more generally. ${ }^{18}$ Their visible prosperity and success within settler society hid the tensions within the intimate domains of the home, as John Howell sought to refashion himself from whaling elite to gentleman.

John Howell was born in 1809 at Fairlight on the Sussex coast, but left home in his early teens. He arrived in Sydney as a cabin boy, working his way up to become the manager of John Jones' newly established whaling station in the Foveaux Strait. Considered an influential force behind the success of the station and the new community at Jacob's River, Howell was known as the 'father of the place'. ${ }^{19}$ Despite being established later than the other stations in the Otago and Southland area, by the time of Wohlers' visit in 1846 the Jacob's River/Aparima settlement had become the largest and arguably most successful in coastal Foveaux Strait, bringing in larger quantities of oil than other stations as well as beginning to expand into pastoralism on the surrounding plains. ${ }^{20}$ Howell became the first agriculturalist in Foveaux Strait, introducing the first cattle, sheep and, then infamously, rabbits. Underpinning both the 
success of the station and his personal success were two prominent marriages, which created kinship connections to local Kāi Tahu as well as providing crucial access to land.

The permission of chiefly leaders (rakatira) was essential to the permanent and peaceful establishment of whaling stations at Jacob's River and elsewhere along the southern coast. Family recollections suggest that Howell's initial reluctance to marry was overcome in part by the need to ensure security for the whaling station and avoid conflict with local Kāi Tahu. ${ }^{21}$ Accordingly, Howell's first marriage was with Kohikohi, the daughter of chief Patu of Centre Island/Raratoka in 1836. The marriage brought Howell status and trading connections to the family (whānui) of Kohikohi as well as the customary title to 50,000 acres of land surrounding the present day township of Riverton which underpinned his expansion into pastoralism as whaling declined in the area from the late 1840s. Together they had two children, George/Teoti and Sarah Ann/Teriana, before Kohikohi's death, aged approximately 23 years, in late $1841 .^{22}$

Like many interracial unions at this time, Howell and Kohikohi's marriage was solemnized according to native custom, as there was no means of formalizing such unions in the European sense. Howell's marriage involved escorting his bride to her new home at Jacob's River/Aparima, followed by days of feasting and celebration. Public acknowledgement was the most significant aspect in confirming the union: 'When he held out his hands and drew her to him the congregation of whalers and Maoris on the beach bore witness to the fact that he gladly accepted her, as his wife. ${ }^{23}$ Ceremonial rituals, like those for Kohikohi and Howell, were the domain of the chiefly families. ${ }^{24}$ Other marriages were confirmed more simply by the handing over of the wife to the husband (pākūwhā), often after the couple had been living together for some period. It is likely that such public acknowledgement and acceptance was all that early interracial marriages consisted of, though there is generally little information available to confirm this. ${ }^{25}$ Whether or not some form of marriage rite was used, it is clear that the acceptance of the wider community was generally a crucial factor in such early interracial marriages. 


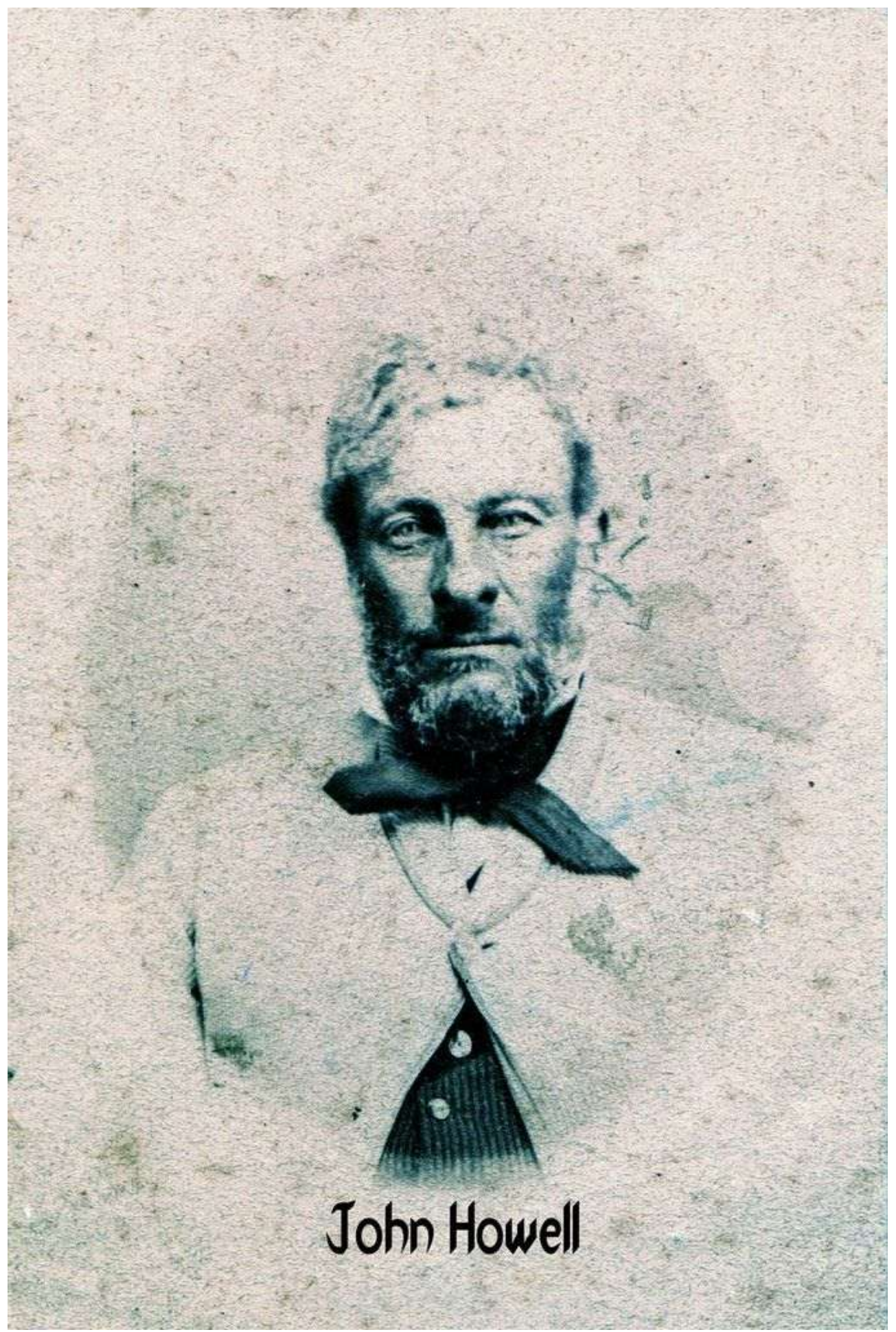

Figure 2. Captain John Howell, no date. Image reproduced courtesy of the Wallace Early Settlers Association.

After the death of his first wife Howell sought to marry again and, following the general trends in whaling settlements of the time, married one of the first generation of mixed race children born in Foveaux Strait, Caroline/Koronaki Brown, the daughter of Captain Robert Brown and Wharerimu of Codfish Island/Whenua Hou, who had been raised amongst her Kāi Tahu kin after the death of her father. This marriage took place in 1845 according to Māori custom and was formalized in a Christian sense at the Waikouaiti mission station the following year. ${ }^{26}$ Taking place 
on the eve of formal colonization, during a period of significant change which irrevocably altered the whaling world, the solemnization of this marriage reflects the growing presence and influence of missionaries, and of the European values and social norms they embodied, in the southern region. ${ }^{27}$

Remarriage was frequent: many Kāi Tahu wives died at a younger age than their partners, while newcomer husbands were frequently drowned or lost at sea due to the dangerous nature of the early sealing and whaling industry. Many individuals in the area had multiple partners during this period as a result. ${ }^{28}$ This pattern also reflects the fact that the early Foveaux Strait community was a youthful one: newcomers frequently arrived in their teens and often married quickly. ${ }^{29}$ The fact that many men thereby established family attachments created the 'tender ties' that would bind them to the local community and the region for decades. ${ }^{30}$

Throughout his life Howell remained aware that much of his success owed to the fact he had 'married in' to Kohikohi's family, and that such kinship connections brought with them duties as well benefits. George Howell recounts the familiar presence of a proportion of the local Kāi Tahu living on his father's land, a reflection of the mutual social obligations between Kāi Tahu and newcomers that were created and sustained through interracial marriage. John Howell provided for these families 'because it was his duty to do so. It was their land. He was only making use of it'. ${ }^{31}$ More broadly, George Howell's memories attest to the fact that, for much of the nineteenth century, the world in which his and other mixed race families lived was one that existed close to, and was in many ways governed by, the norms and authority, of Kāi Tahu society.

In the same manner, interracial marriages of the early nineteenth century generally took place according to Kāi Tahu understanding of status and social hierarchy. The daughters and nieces of rakatira intermarried with 'Europeans who stood out in some way', especially whaling station owners or managers such as Howell. ${ }^{32}$ This pattern suggests that during this period such men held enough standing in the eyes of Kāi Tahu to marry well, and were perceived as matches which either maintained or improved social status. ${ }^{33}$ These were partnerships that generated status and respect (mana) not only for the women but also for her family, underscoring the fact that marriages were as much about creating connections between communities as between individuals. ${ }^{34}$ Interracial intimacy was never divorced from the wider social and political context, and because of this these relationships drew men into the obligations as well as the privileges associated with kinship networks.

It was predominately, if not exclusively, male newcomers who married indigenous women during this period, a pattern also identified in Canada during the fur trade era. ${ }^{35}$ In part this trend reflects the fact that European women were not present in significant numbers until the 1860s. While interracial marriage was rare for indigenous men, Kāi Tahu and mixed descent men frequently found employment on whaling vessels, and later in ship-building enterprises through new kinship connections. For example, John Howell managed John Jones' station at Jacob's River/Aparima, but while he was engaged in overseeing his pastoral runs, his brotherin-law Captain Thomas Brown and Captain 'Paddy' Gilroy acted as the station managers as well as captaining whaling ships. ${ }^{36}$ These relationships suggest that the early Foveaux Strait whaling and trading industries were maintained through a complex web of economic and social networks, and demonstrate that although interracial marriage involved indigenous women marrying out, it also offered indigenous and mixed race men particular social and economic opportunities. 
Whether simply because of the relative number of young mixed descent women, personal preferences or social attitudes, the second and subsequent partners of male newcomers in the region were predominantly mixed race or European, rather than Kāi Tahu, such as Howell's second wife, Caroline. ${ }^{37}$ In this manner, upon the advent of formal colonization, patterns of interracial marriage in New Zealand, like in other colonial societies, shifted towards a preference for mixed race wives. In part, this occurred because, demographically, mixed race women made up an ever greater proportion of the Kāi Tahu population while European women remained scarce into the 1850s. However, this trend may equally reflect a growing concern with social respectability by settler men: mixed race women of good standing, appearance and perhaps education were often considered able to pass more easily in settler society. Wohlers' comments on the wife of William Stirling, Mary (née Parker) emphasize the belief that mixed race women could 'pass' in settler society: 'Mrs Stirling is a halfcaste, but she had had the luck to have been educated by her father, an Englishman. She is the crown of women at Foveaux Strait and one cannot at all notice that she is a half-cast [sic]. She is so pretty, so friendly, so quick and so clever that one might envy Stirling for her. ${ }^{38}$ As the century progressed, individuals of mixed race also tended to marry each other. ${ }^{39}$ Indeed, during an 1855 visit to Jacob's River/Aparima, Wohlers observed that almost all the mixed race families living in the community of about a hundred were related by marriage, an observation that probably held true for most settlements in the area. ${ }^{40}$ Growing up together, these children held lifelong connections, which were reflected and reinforced by cross-generational marriages. Such partnerships produced dense kinship ties, and meant mixed race individuals remained a part of the broader Kāi Tahu whanui.

\section{Koronaki's story: mixed race respectability}

Interracial families like the Howells retained strong connections with Kāi Tahu relatives and society, but this relationship altered as land sales and the pace of European settlement in the region increased. As the century progressed, this integration of two cultural traditions within the intimate setting of the family increasingly became the source of ambivalence for mixed race individuals. Such ties could thus be terse, tense, as well as tender. ${ }^{41}$ Many of the tensions surrounding the social world and cultural affiliation of mixed race individuals at mid-century are exemplified by the experience of Koronaki Howell, who found that, during the course of her marriage, class and respectability became of increasing importance as polite settler society became established in the southern regions from the $1850 \mathrm{~s}$.

On 10 August 1845, at the age of 13, the 'dainty and attractive' Caroline/ Koronaki Brown became the second wife of John Howell according to native custom. ${ }^{42}$ Wohlers visited Caroline not long after she formally married. His observations offer valuable insight into the challenges this relationship held for the young bride:

She has lost her father when she was a child, and hence she has grown up among the natives without any European education. She does not know any English but that which she has learnt during the few months of her marriage. Howell wants to civilise her and to make her outstanding among other women. Hence he does not allow her to sit around among the other natives, nor to attend the Māori church services which are lead by a native teacher. This however is not hostility against Christainity but he won't permit that his wife should sit among the natives and he does not want that the native teacher should exercise a popish compulsion on her faith... Caroline's 
situation makes her indeed somewhat lonely; for she does not know how to behave among the European women, of whom there are three in this place and hence she does not feel comfortable in their company. She is not allowed to keep close contact with the natives. Neither yet is she conscious of her status. Hence I tried to fill her with pride and put it to her that she was superior to the other women of this settlement. She was the wife of a gentleman and hence must not associate with women who stood far below her. One should think that such exhortations would impress the heart of a young and pretty women but I could not notice any such impression. If she would have her own way, she would bother very little with the household, but would sit among the natives most of the time. She really is still too young. ${ }^{43}$

Wohlers' interpretation of Caroline's married life suggests a great deal about the social world of interracial families in southern New Zealand, the intimate aspects of family life in interracial partnerships, and about the value judgments made about her behaviour, both as a mixed race woman and as a wife of a 'gentleman'. Despite the pleasure that many found in interracial partnerships, the differing values and expectations held by Māori and Pākehā could also be source of conflict, not only in colonial society generally, but also at the familial and personal level within interracial relationships.

The patterns of interracial marriage engaged in by Howell demonstrate that the social world of mixed race families was not static and unchanging. From 1844 to 1864, increased European settlement of the South Island was facilitated by a series of land purchases which brought over 34 million acres under the control of the colonial government, leaving only a small proportion under customary title. ${ }^{44}$ In the 1864 deed of sale for Stewart Island/Rakiura, the colonial government acknowledged 'halfcastes' as a legal and social entity, separate from both the Kāi Tahu and from the settler community, requiring distinct management and protection by the colonial administration. The terms of the purchase included provisions for the establishment of a 'half caste' reserve at The Neck on Stewart Island/Rakiura, separate from those lands set aside as native reserves. This provision represented a marked break from previous land purchases in the South Island, which made no mention of, or provisions for, the mixed race population and foregrounds the emergence of a significant interracial community around Foveaux Strait. ${ }^{45}$ Moreover, the demographic transformation resulting from such interracial relationships and marriages has had ongoing significant social, economic and political impact on Kāi Tahu. As a result of this process of cultural mixing and hybridity, Kāi Tahu have been labelled 'the white tribe' in contemporary New Zealand. ${ }^{46}$

The presence of three European women in Riverton, mentioned by Wohlers in 1846, signalled a departure from the earlier decades of sealing and whaling in which newcomers to the region were strictly male. The growing presence of white women was but one aspect of a broader transformation of the local population. By the time of the Stewart Island/Rakiura land purchase in 1864, the non-Māori population first equalled and then exceeded that of the Māori population, in a process popularly termed 'swamping'. ${ }^{47}$ This demographic shift began in earnest in southern New Zealand with the beginnings of the Scottish Free Church settlement in Otago in 1848. The arrival of increasing numbers of European men, and later women and families, changed the dynamics of interracial marriage throughout the Foveaux Strait area. 
The resultant changes on the social and economic landscape had significant effects on the mixed race population. Issues of education and status gained greater importance for many mixed race families, often emphasized by Pākehā husbands and fathers concerned about their standing, and that of their children, in the rapidly changing colonial society at a time when the colonial government deployed a race relations policy based around cultural assimilation, which was particularly focused on education. For others, the issue of land ownership took on much greater importance. Many mixed race individuals found themselves in a state of poverty and landlessness as government land purchases and agricultural settlement expanded. ${ }^{48}$ In this context, a division emerged between mixed race families who remained embedded in the Kāi Tahu and maritime environment, and those such as the Howells who sought to retain the pre-eminence they had held during the whaling era.

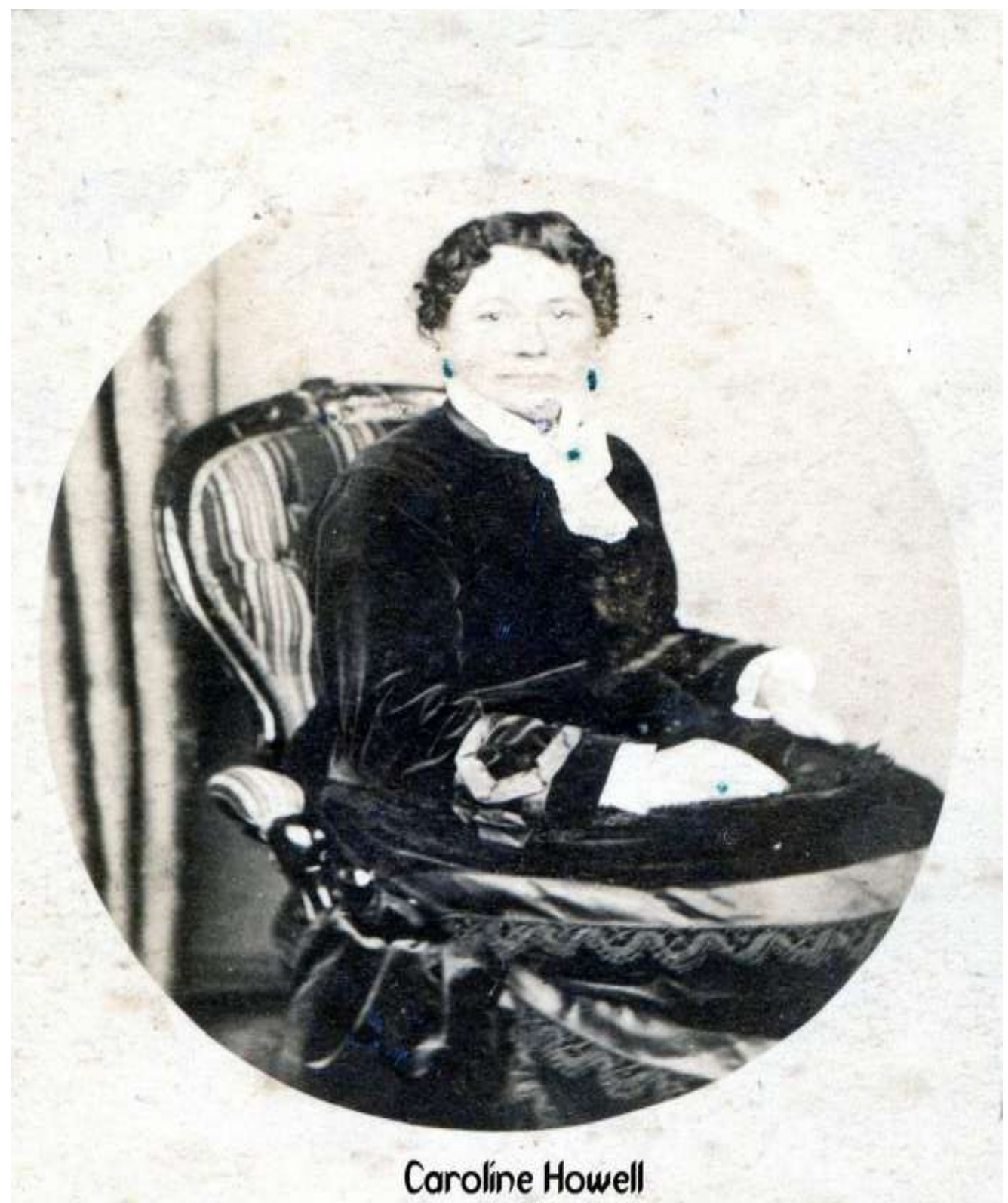

Figure 3. Koronaki, also known as Caroline Howell, no date. Image reproduced courtesy of the Wallace Early Settlers Association. 
It is important to emphasize here that the trajectory of the Howell family from the 1850s was quite distinct from many mixed race families who lacked the access to land, wealth and appropriate social capital. Such families were often living in isolated situations and marginalized from colonial society by the end of the century, reliant on the traditional support networks of their Kāi Tahu whanui for survival. The imprint of these individuals on the historical record is also faint, but petitions to the government from both the fathers of mixed race children and from Kāi Tahu relatives highlight their pitiful state and suggest that tensions existed over increasingly scarce land and resources. The divergent experiences of the mixed race community is reflected in government censuses from 1853, which made a distinction between 'half-castes living as Maori' and 'half-castes living as Europeans', signalling that racial identity was officially constituted and reinforced by behaviour and lifestyle as well as by blood. ${ }^{49}$

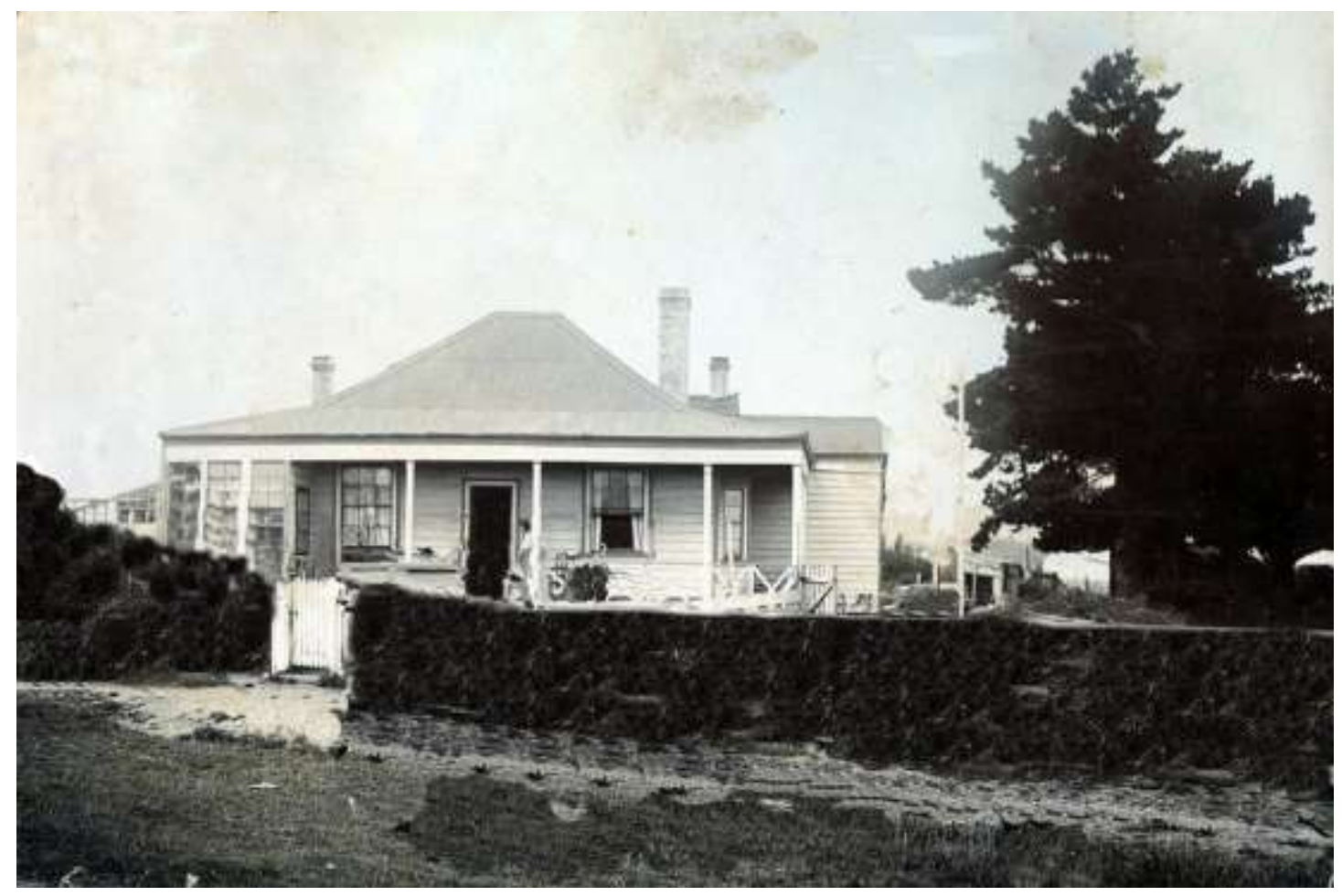

Figure 4. The Howell residence at Riverton, which was built in 1847. This photograph dates to 1907. Image reproduced courtesy of the Wallace Early Settlers Association.

Increasing European settlement coincided with the decreased profitability of whaling. As a result, John Howell re-focused his attention on pastoral development around the Jacob's River/Aparima area, utilizing the 50,000 acres of land extending from Fairfax to Wrey's Bush he was gifted upon his first marriage. ${ }^{50}$ Indeed, the land holdings gained through this marriage gave him a significant material advantage and, more crucially, enabled his transition from maritime merchant to a colonial gentleman. From the mid-1840s Howell began to import sheep and cattle from New South Wales and he increasingly focused his energy on his pastoral runs. At the time of his death in 1874 he held '100,000 acres of Leasehold land and 1000 acres of Freehold land, together with 40,000 sheep and 1000 head of cattle in the Wakatipu area, besides an extensive area of land in the Riverton locality'. ${ }^{51}$ The wealth generated through these estates enabled Howell to provide his family with the right cultural capital, the right 
education and connections to maintain their privileged social and economic position throughout the nineteenth century.

Howell's desire to distinguish his as the leading family within the community was reflected in the changing landscape of the Jacob's River/Aparima area, as the settlement was transformed from whaling station to colonial township. This transformation was mirrored by a shift in the heart of the European and mixed race settlement to the north side of the river, initiated when Howell built 'a home more befitting a prosperous landowner' on what is now Riverton's main street in $1847 .{ }^{52}$ Other families followed Howell's lead, marking the beginning of the township in its present form. In the 1860s, the Howell family shifted again to a stately homestead on the Fairlight run (Run 352) near Garston. Koronaki's interest in land in the Port William area was also exchanged in order to increase the family's inland estate holdings. ${ }^{53}$ Their Riverton property was retained as a 'town house', a reflection of the family's wealth and their attempt to replicate the lifestyle of the upper class in the metropole. $^{54}$

For other mixed race families too, housing provided a visible means of demonstrating material wealth and status. At Halfmoon Bay on Stewart Island, Lewis Acker, who was then married to Mary Pii, had a cottage constructed of stone transported in from New River at great difficulty, which became known as 'Ackers Castle'. ${ }^{55}$ Similarly the weatherboard home of James Spencer and Mere Kauri stood out as a sign of affluence amongst the thatched houses in Bluff. ${ }^{56}$ The homes of mixed race families were the sites of important social functions within the early community, as they hosted missionary services and accommodated numerous guests. ${ }^{57}$ As houses became homes, they formed a key space in which families could display affluence, respectability, and social refinement. ${ }^{58}$

As well as economic success, John Howell sought to transform his children into respectable members of settler society. Along with the two children from Howell's first marriage, he and Koronaki had 17 children over the course of their marriage. In the 1840s, Howell established a small informal school at Jacob's River/Aparima, with one of the more educated whalers, John Lidyard, as schoolmaster. ${ }^{59}$ Although they gained a basic education within the settlement, Howell sought a much more extensive education for his own children, sending his eldest son George to live with his friend William Portland in Sydney to be educated alongside the Portland children. The social graces learnt there earned George the epithet 'old gentleman Howell'. ${ }^{60}$ All the Howell girls also received a thorough education at St Dominic's Convent in Dunedin, where the sisters had a dormitory to themselves. ${ }^{61}$ This level of schooling was unusual for girls during much of the nineteenth century, and indicates the standing of the Howell family amongst the colonial elite in southern New Zealand.

Howell was not alone in regarding European education as a crucial factor for the chances and opportunities of their mixed race offspring in colonial New Zealand. Wohlers noted the desire of most fathers to have their mixed descent children educated, however the expense and geographical remoteness limited access within the Foveaux Strait and Stewart Island/Rakiura region. ${ }^{62}$ Men (like Howell) who had money and connections sent their children away for an education, while many children from Stewart Island/Rakiura families were sent to live with relatives on Ruapuke once a school was opened there in $1868 .{ }^{63}$ From the perspective of both Howell and Wohlers, a 'good' (meaning English) education was a key mechanism for mixed European-Māori families to demarcate status and affluence from the 1840s onwards, and a means by which those families and individuals who did gain a suitable 
education could assert their right to a place in the polite society of the growing settler population.

Although Caroline/Koronaki did not have the opportunity for formal education like her children, Howell made efforts to educate his young bride in a more informal manner. In particular, he attempted to restrict the influence of her Kāi Tahu relatives and the 'popish' native teacher, and instead surround her with the civilizing presence of his European family members. In doing so, Howell appeared to be creating an increased social distance between his family and the Kāi Tahu whanui, suggesting a tension between acknowledging kinship (whakapapa) as the basis of his success and the desire to further cement his position within colonial society.

Christianity was another means through which families expressed their respectability, values and status. In the eyes of Wohlers and other missionaries especially, the active and public practice of Christianity distinguished the leading 'gentlemen' of the mixed race settlements from those men who 'don't lift a finger to civilise their wives'. ${ }^{64}$ During visitations around the Foveaux Strait settlements, Wohlers and Bishop Selwyn stayed and held their services within the houses of Howell, Stirling, and Anglem in the absence of a local church. ${ }^{65}$ Through the public expression of Christianity along with associated social values, these men presented themselves as embodying a particular vision of masculinity: as educated, moral and responsible fathers and providers. In doing so, they set themselves apart from the negative stereotype of drunkenness and associated unruliness often levelled at the southern whaling communities. ${ }^{66}$

Marriage and kinship networks within European society further operated to ensure the Howell family's prominence within the local community. Just as an aristocratic marriage to Kohikohi brought with it both mana and the land that underwrote his wealth and agricultural success, Howell's personal connections across the settler community and within local politics were indicators of, and a foundation for, his social and political prominence. The earliest European settlers at Jacob's River/Aparima were relatives of Captain John Howell: his step-siblings William Stevens, George Stevens, Ann Paulin (née Stevens) with husband John Paulin, and Elizabeth Stevens, who married settler Theophilus Daniel at Ruapuke. ${ }^{67}$ William Stevens became a partner of the whaling station and worked with Howell to introduce the first cattle and sheep to the region. Previously the station storekeeper, Theophilus Daniel became a member of the Provincial Council, member of House of Representatives for Wallace from 1882-1884, and Mayor of Riverton for two terms in 1879 and 1881. ${ }^{68}$ Extended family provided economic partnerships and political connections for the Howells. Indeed, the leading citizens of early Riverton were all connected in this way. Whether operating within the context of Kāi Tahu or European settler society, such webs of kinship could be a crucial source of identity, status, wealth, social connections and obligations for mixed race families like the Howells.

While Howell appears successful in cultivating himself and his family as prominent and respectable within European settler society, the transition was not necessarily an easy one for his second wife. Her prominent marriage and the expectations it brought left Caroline/Koronaki feeling isolated from those Kāi Tahu relatives with whom she had previously associated. Despite recognizing this, in his account Wohlers failed to appreciate that the importance placed on western concepts of respectability and status by her husband and European society more generally held little meaning to Caroline/Koronaki who, at least during the initial stages of her marriage, felt more a part of a Kāi Tahu cultural milieu than of the emerging European colonial society. In part this ambivalence, and the adjustments made in her 
marriage, reflects the broader social and economic changes experienced by the Howell family from the 1840s onwards, embodied in the shift from the whaling station to the pastoral homestead. ${ }^{69}$

As a person of part-European descent, Caroline/Koronaki was expected to be able to understand and conform to the values of European society better than a 'fullblood' Kāi Tahu woman, despite the fact she had never lived in a European social setting, nor had the opportunity to learn the language or appropriate cultural affiliations. In some ways, Caroline's situation is likely to reflect that of other mixed race individuals who were brought up by their Kāi Tahu relatives. ${ }^{70}$ However, unlike Caroline/Koronaki, many of these individuals remained 'half-castes living as Māori' according to government censuses of the southern Kāi Tahu population, which indicates that they remained largely within a Kāi Tahu milieu throughout their lives. ${ }^{71}$ In contrast, the disjunction between her childhood experiences and her social position after marriage placed Caroline/Koronaki in an uncomfortable liminal space. Without the presence of her European father, Caroline/Koronaki lacked the opportunities to learn the language and cultural capital that gave other mixed race women a degree of ease in navigating between the different social worlds of their Kāi Tahu relatives and their newcomer husband.

Although initially uncomfortable with her ambiguous position between these societies, through the course of her marriage Caroline/Koronaki appears to have adjusted. A visitor to the household, Riverton historian J.C. Thomson praised Caroline/Koronaki for her talent as hostess, describing her as 'a well-favored, black eyed brunette whose modest and shy manners embellished, rather than detracted from her charms. ${ }^{, 72}$ It appears that Koronaki coped well with the challenges of navigating polite social encounters, and by the time the family relocated to Fairlight, she had become known for her warm-hearted hospitality. ${ }^{73}$ Her eldest son recalled the pleasure she derived from shopping trips to Riverton in later years, while her probate indicates that on a material level, she was very well provided for and held significant property in her own right. ${ }^{74}$

Unfortunately it is difficult to comment further on Caroline/Koronaki's life after the death of her husband in 1874. Although she lived 25 years longer than her husband, passing away at age 67 in 1899, the accounts of her life drawn on above are generally told through the perspective of contemporaneous male commentators like Wohlers, reflecting the uneven nature of the archive. However, a number of photographs of Caroline/Koronaki and the Howell children have been preserved and offer another window onto the changing lives of the family. Like other demonstrations of cultural capital, photographs provided an avenue for the Howells to display and affirm their social identity in a very material and lasting way. In photographs, Caroline/Koronaki is presented as a proper colonial gentlewoman, attired in European dress and modestly seated amongst gentile furnishings. Early albums of the family, primarily studio portraits contain little trace of Caroline/Koronaki's Kāi Tahu ancestry, highlighting the success of the Howell's transformation to colonial gentry across the nineteenth century. For those with a knowledge of local genealogy, this kind of analysis of visual and material culture is too simplistic, rendering invisible the history of interracial marriage and the underlying importance of whakapapa and community to the Howell family and the settlement of southern New Zealand more broadly. This history remains clearly visible in a photograph of Caroline/Koronaki with her sister Elizabeth/Peti, the wife of Tame Parata, member of the House of Representatives for Southern Maori from $1885 .^{75}$ As a closer viewing of such photographs demonstrates, a fine-grained 
examination of the Howell family thus reveals a more complicated and nuanced experience of living 'in-between worlds' than traditional portrayals suggest.

\section{Conclusion}

The 'tender ties' of interracial marriage were a defining aspect of the colonial experience for Kāi Tahu in the Foveaux Strait, as exemplified by the demographic transformation that occurred in the region. These intimate bonds integrated Kāi Tahu and newcomers into a complex socio-economic community that encompassed far more than oversimplified labels such as 'sex industry', with its purely economic connotations, can possibly convey. The kinship ties cemented through interracial marriage were critical to the successful formation of southern whaling stations such as Jacob's River/Aparima, offering European newcomers land and security, while providing Kāi Tahu with increased mana, trading, and employment opportunities.

The Howell family were both typical and atypical of the era and region. While the patterns of interracial marriage engaged in by John Howell and his children reflect the changing trends in interracial intimacy in Foveaux Strait across the nineteenth century, Howell's wealth and land holdings meant their lives increasingly diverged from other mixed race families. After the closure of the Jacob's River/Aparima whaling station, many families lived an increasingly impoverished existence. However, for mixed race families with access to material and cultural capital such as the Howells, Christianity, education and housing, along with whakapapa on the European side, took on increasing significance in demarcating respectability in the changing colonial world of the mid-nineteenth century.

Caroline/Koronaki's marriage certainly offered her 'every comfort of a civilised life', but this did not mean that the transition to being the young wife of an increasingly affluent and ambitious whaling captain was an easy one. Removed from the support and familiarity of her Kāi Tahu relatives, she was expected to adapt easily to European society by virtue of her mixed ancestry. The adaptations to the new respectable and increasingly European lifestyle made by Caroline/Koronaki over the course of her marriage reflect the broader social changes that occurred in the region, as the whaling station of Jacob's River/Aparima declined and the colonial township of Riverton emerged in its place. As the young Caroline/Koronaki discovered, the process of refashioning identity and asserting status in an emerging settler society was one surrounded by ambivalence and loneliness for mixed race individuals. Despite this, the Howells successfully achieved prominence within local settler society, indicating that ideas of morality and respectability were far more important in defining and demarcating social status than racial identity.

Caroline/Koronaki's story reminds us that understandings of New Zealand's colonial past cannot be neatly fitted into the straitjacket of colonized and colonizer, Māori and Pākehā. Individuals like Koronaki and mixed race families like the Howells defy such categorizations, as their lives traversed in-between worlds that were perhaps never as distinct or discretely bounded as historical narratives created by tribunals would have us believe. Their story highlights the richness and complexity of colonial experience in New Zealand that can be gained when we metephorically lift up the carpet to look at histories existing 'under the nation', decentre narratives of biculturalism and focus instead on studies of kinship, community and whakapapa. 
${ }^{1}$ Edward Shortland, Southern Districts of New Zealand: A Journal, with Passing Notices of the Customs of the Aborigines (first published in 1851), Christchurch, 1974, pp.149-50.

${ }^{2}$ Michael King, The Penguin History of New Zealand, Auckland, 2003, p.122.

${ }^{3}$ J.F.H. Wohlers, Report Number 10: Travel Report from 30 June to 17 July 1846, Wohlers Collection, MS-0967/017, Hocken Collections (HC), Dunedin.

${ }^{4}$ J.F.H. Wohlers, First Quarterly Report, 1 May 1845, MS-0967/014, HC. See also J.F.H. Wohlers, Memories of the Life of J.F.H. Wohlers: Missionary at Ruapuke: An Autobiography, trans. John Houghton, Dunedin, 1895, p.101. Wohlers frequently described Ruapuke as a 'centre or gathering place'.

${ }^{5}$ Wohlers, Report Number 10; J.F.H. Wohlers, 'Visit to Māori Villages on Mainland 20 December 1857-20 January 1858', MS-0967/026, HC.

${ }^{6}$ Mention of the Howells and the upstanding example of European society they represented are frequently found in the reports and letters of Wohlers as well as of other visiting officials and missionaries. This reputation has survived in posterity, for John Howell and family are regularly mentioned among the pioneer families of the region in local histories. See, for example, F.G. Hall-Jones, Historical Southland, Dunedin, 1945, pp.46, 49, 94 and 102-3; John Hall-Jones, The South Explored: An Illustrated History of New Zealand's Deep South, Wellington, 1979, pp.47-9, 124-6; J.C. Thompson, Records of Early Riverton and District, Invercargill, 1937, p.5. The most comprehensive family history, inclusive of the personal memories of George Howell, is by Eva Wilson, Hakoro Ki Te Iwi: The Story of Captain Howell and his Family, 2nd ed., Invercargill, 2000.

${ }^{7}$ Judith Binney, “In-between” lives: studies from within a colonial society', in Tony Ballantyne and Brian Moloughney, eds, Disputed Histories: Imagining New

Zealand's Pasts, Dunedin, 2006, pp.93-118.

${ }^{8}$ See Jim McAloon, No Idle Rich: the Wealthy in Canterbury and Otago 1840-1914, Dunedin, 2002.

${ }^{9}$ Atholl Anderson, The Welcome of Strangers: An Ethnohistory of Southern Māori A.D. 1650-1850, Dunedin, 1998, p.194.

${ }^{10}$ ibid., p. 195.

${ }^{11}$ Kate Riddell, "A "Marriage" of the Races? Aspects of Intermarriage, Ideology and Reproduction on the New Zealand Frontier', MA thesis, Victoria University of Wellington, 1996, p.130.

${ }^{12}$ Atholl Anderson, Race Against Time: The Early Māori-Pākehā Families and the Development of the Mixed-Race Population in Southern New Zealand, Dunedin, 1991, p.31.

${ }^{13}$ Kerry Howe, 'Two Worlds', New Zealand Journal of History (NZJH), 37, 1 (2003), p.57.

${ }^{14}$ Bill Dacker, Te Mamae Me Te Aroha = The Pain and the Love: A History of Kai Tahu Whanui in Otago, 1844-1994, Dunedin, 1994; Harry C. Evison, The Long Dispute: Maori Land Rights and European Colonisation in Southern New Zealand, Christchurch, 1997; Harry C. Evison, Te Wai Pounamu, the Greenstone Island: A History of the Southern Maori During the European Colonization of New Zealand, Christchurch, 1993; Anderson, The Welcome of Strangers.

${ }^{15}$ Michael Stevens, 'Kāi Tahu me te Hopu Tìt ì ki Rakiura: An Exception to the “Colonial Rule”?', The Journal of Pacific History, 41, 3 (2006), pp.273-91.

${ }^{16}$ Tony Ballantyne, 'On Place, Space and Mobility in Nineteenth-Century New Zealand', NZJH, 45, 1 (2011), p.50. 
${ }^{17}$ Case files - Addenda [Caroline Howell, Port William, Stewart Island, Eyre Mountain], OLC 1 Box 72 OLC 2A, Archives New Zealand, Wellington (ANZ-W); Probate for HOWELL John - Fairlight Station - Runholder, 1876, DAFG 9066 D328 Box 2 Record 76 and 93, Archives New Zealand, Dunedin (ANZ-D); Probate for HOWELL Caroline - Riverton, 1899, DAFG 9071 D328 Box 324 Record 617, ANZD; Probate for HOWELL Caroline - Riverton - Widow, 1899, DAFG 9066 D328 Box 11 908, ANZ-D; Wilson, Hakoro Ki Te Iwi.

${ }^{18}$ Hall-Jones, Historical Southland; Hall-Jones, Invercargill Pioneers; F.G. HallJones, Kelly of Inverkelly: The Story of Settlement in Southland 1824-1860, Invercargill, 1944; John Hall-Jones, Bluff Harbour, Bluff, 1976; Hall-Jones, The South Explored; Basil Howard, Rakiura: A History of Stewart Island, New Zealand, Dunedin, 1940; Robert McNab, Murihiku and the Southern Islands, Invercargill, 1907; Sheila Natusch, An Island Called Home: Rakiura, Stewart Island, Invercargill, 1992; Olga Sansom, The Stewart Islanders, Wellington, 1970; Paul Sorrell, ed., Murihiku - The Southland Story, Invercargill, 2006; Thompson, Records of Early Riverton and District.

${ }^{19}$ Wilson, Hakoro Ki Te Iwi, p.3.

${ }^{20}$ J.F.H. Wohlers, Report Number 12, 10 September 1846, MS-0967/017, HC; HallJones, Historical Southland, p.46.

${ }^{21}$ Wilson, Hakoro Ki Te Iwi, pp.8-9.

${ }^{22}$ The cause of Kohikohi's death is unknown. She is buried on Centre Island/Raratoka.

${ }^{23}$ Wilson, Hakoro Ki Te Iwi, p.10. Nathaniel Bates and his first wife Hinepu were married according to Māori tradition around 1839-1840: Linda J. Scott, Finlay Bayne and Michael J. F. Connor, Nathaniel Bates of Riverton: His Families and

Descendants, Christchurch, 1994, p.17.

${ }^{24}$ Biggs, based on the evidence of Elsdon Best, states that 'The patrician, or aristocractic wedding ... consisted of a ceremonial at which ritual spells known as whakapiri (cause to cling), and ohaoha (blessing) were repeated over the couple. A feast was held which was known as umu kootore (kai kootore, kai reperepe). The whole ceremony was generally known as umu kootore (oven of the tail end) ... [this ceremony] distinguished the aristocratic from the ordinary wedding.' By contrast, being found after a night together was a common means by which a couple would make public their relationship, though generally it would take some time living together for the union to be accepted. Bruce Biggs, Maori Marriage: An Essay in Reconstruction, Wellington, 1960, pp.40-1.

25 ibid.

${ }^{26}$ Wilson, Hakoro Ki Te Iwi, p.23.

${ }^{27}$ Both Wohlers, Watkins and Bishop Selwyn identify strong religious beliefs and love for their partners as key reasons for uptake of Christian marriage from the mid1840s onwards. Less naïvely (or more cynically, depending on one's perspective), James Watkin also noted that 'the white men almost generally are living with Native women, and my coming here is looked upon rather suspiciously by them, for they know enough of Christianity to be aware that if it prevails they must either marry the women or lose them.' Reverend James Watkin, cit. 'Ninety Years Ago: First South Island Mission. Dairy of the Rev. James Watkin. Struggles with the Language', Press (Christchurch), 30 June 1931, Newspaper clippings album, number 6, 18, James Herries Beattie Papers, MS-582/A/6, HC. 
${ }^{28}$ Apart from Howell, these include Nathaniel Bates, William Palmer, George Printz, Hineawhitia, Waa and others.

${ }^{29}$ For example, George Printz arrived at Preservation Inlet in 1837 at the age of just ten years. Over the course of the following five decades, he married three times to Margaret/Pokuru (daughter of Huruhuru), then to Catherine Risetto (daughter of Lewis Acker and Mary Pi) and finally to Matilda Howell (daughter of John Howell and Caroline/Koronaki Brown). See Hall-Jones, Invercargill Pioneers, pp.38-9, and Ruapuke Registers Vol. 1, 5 (Entries 52 \& 54), HC.

${ }^{30}$ Sylvia Van Kirk, Many Tender Ties: Women in Fur Trade Society, 1670-1870, Winnipeg, 1980.

${ }^{31}$ George Howell, cit. Wilson, Hakoro Ki Te Iwi, pp.31, 59.

${ }^{32}$ Anderson, Race Against Time, p.7.

${ }^{33}$ For further discussion of the wider social considerations in 'aristocratic' marriages in Māori society, see Biggs, Maori Marriage.

${ }^{34}$ Erik Olssen, 'Families and the Gendering of European New Zealand in the Colonial Period, 1840-80', in Caroline Daley and Deborah Montgomerie, eds, The Gendered Kiwi, Auckland, 1999, p.39.

${ }^{35}$ See Van Kirk, Many Tender Ties; Sylvia Van Kirk, 'Colonized Lives: The Native Wives and Daughters of Five Founding Families of Victoria', in Mary-Ellen Kelm and Lorna Townsend, eds, In the Days of Our Grandmothers: A Reader in Aboriginal Women's History in Canada, Toronto, 2006, pp.170-99.

${ }^{36}$ Wilson, Hakoro Ki Te Iwi, p.36.

${ }^{37}$ Anderson, Race Against Time, p.9.

${ }^{38}$ Wohlers, Report Number 12.

${ }^{39}$ ibid.

${ }^{40}$ J.F.H. Wohlers, Letter to Committee of Administration, 5 June 1855, MS0967/025, HC.

${ }^{41}$ Ann Laura Stoler, 'Tense and Tender Ties: The Politics of Comparison in North American History and (Post) Colonial Studies', The Journal of American History, 88, 3 (2001), pp.829-65.

${ }^{42}$ Wilson, Hakoro Ki Te Iwi, p.23.

${ }^{43}$ Wohlers, Report Number 12.

${ }^{44}$ Waitangi Tribunal, The Ngai Tahu Report, 1991, Wellington, 1997, p.xiv. These purchases and their historical significance for Kāi Tahu are explored in Dacker, Te Mamae Me Te Aroha, and Evison, The Long Dispute.

${ }^{45}$ The text of the 1864 Rakiura deed of purchase is transcribed in Harry C. Evison, The Ngāi Tahu Deeds: A Window on New Zealand History, Christchurch, 2006, ch.15.

${ }^{46}$ Hana O’Regan, Ko Tahu, Ko Au: Kāi Tahu Tribal Identity, Christchurch, 2001, p. 25 .

${ }^{47}$ James Belich, Making Peoples: A History of the New Zealanders From Polynesian Settlement to the End of the Nineteenth Century, Auckland, 1996, p.249.

${ }^{48}$ Investigating the position of South Island Māori (including 'half-castes') in 1890, Alexander Mackay found that over $90 \%$ had either insufficient or no land. Report by Mr Commissioner Mackay Relating to Middle Island Native Claims, Appendices to the Journals of the House of Representatives (AJHR), 1891, G-7, pp.1-7.

${ }^{49}$ AJHR, 1876, G-9, p.23.

${ }^{50}$ Wilson, Hakoro Ki Te Iwi, p.10. His second marriage also brought Howell access to land given to Caroline/Koronaki Brown by Horomona Patu at Port William on 
Stewart Island/Rakiura, which was eventually secured through an Old Land Claim and exchanged for a grant around Eyre Mountain. See Walter Pearson to Land Claims Commissioner, Wellington, 17 November 1870, Case files - Addenda [Caroline Howell, Port William, Stewart Island, Eyre Mountain].

${ }^{51}$ Obituary in New Zealand Mail, 29 August 1874; Probate for HOWELL John.

${ }^{52}$ Wilson, Hakoro Ki Te Iwi, pp. 23, 25-6.

${ }^{53}$ Case files - Addenda [Caroline Howell, Port William, Stewart Island, Eyre Mountain].

${ }^{54}$ Wilson, Hakoro Ki Te Iwi, pp.31-2.

${ }^{55}$ Mary Pii (or Pui) was born around 1820 and was the daughter of Kaniua and Hine Pipiwai of Kaiapoi. She and Acker formally married on 4 March 1844 at Stewart Island, some years after a Māori ceremony had confirmed their relationship. They had nine children before Mary's death, and Acker subsequently remarried an immigrant from Tasmania. Acker Family, 1834-1984, Invercargill, 1984; P.D. Garven, The Genealogy of the Ngāi Tahu, III, Christchurch, 1977-2002, p.41; Hall-Jones, Kelly of Inverkelly, p.37; Howard, pp.88-90; Sansom, The Stewart Islanders, pp.22-30; Ruapuke Registers Vol. 1 Baptisms, 1850-1885, 8 (Entries 106-109) and 10 (Entry 137), HC; Otago and Southland Early Settlers Database, Otago Settlers Museum (OSM), Dunedin.

${ }^{56}$ Georgina Ellis, Time and Tide: Ramblings, Recollections and Reminiscences of the Spencer Family, 2nd ed., Invercargill, 2000, pp.20-1. Mere Kauri was the second wife of Spencer, and they became the first recorded Christian union upon their marriage by James Watkin at Waikouaiti in January 1841. Spencer was previously partnered with Hineraukawakawa (Pina). See Ruapuke Registers Vol. 4, 34 (Entry 118), HC; Garven, The Genealogy of the Ngāi Tahu Vol. 1, Tables 5b \& 8c; HallJones, Bluff Harbour, pp.17-20.

${ }^{57}$ Wohlers, Report Number 10 and Report Number 12; Wilson, Hakoro Ki Te Iwi, p.10; J.T. Thompson cit. Hall-Jones, The South Explored, p.126.

${ }^{58}$ Wilson, Hakoro Ki Te Iwi, p.33; Hall-Jones, The South Explored, pp.125-126.

${ }^{59}$ Wilson, Hakoro Ki Te Iwi, p.21.

${ }^{60}$ ibid., p. 25.

61 ibid., pp.66, 71.

${ }^{62}$ Wohlers, Report Number 10; J.F.H. Wohlers, Report Number 14, 21 December 1847, MS-0967/018, HC.

${ }^{63}$ J.F.H. Wohlers, Letter to Inspector Zahn, 15 June 1868, MS-0967/027, HC.

${ }^{64}$ J.F.H. Wohlers, Report Number 4, 1 May 1845, MS-0967/014, HC.

${ }^{65}$ Wohlers, Report Number 10; Wohlers, 'Visit to Māori Villages'. William Stirling and Captain William Andrew Anglem married Mary Parker (mixed descent daughter of John Parker) and Te Anau/Maria (daughter of Te Wakaihau and Hinepohia) respectively and were the fathers of prominent families in Bluff and The Neck. 66 Shortland, pp.152-53; J.F.H. Wohlers, Ruapuke Report Number 7, MS-0967/014, HC; Wohlers, Report Number 12.

${ }^{67}$ Wilson, Hakoro Ki Te Iwi, p.19; Hall-Jones, Historical Southland, p.49.

${ }^{68}$ Thompson, p.27; Hall-Jones, Historical Southland, p.49.

${ }^{69}$ Wilson, Hakoro Ki Te Iwi, pp.31-32.

${ }^{70}$ Wohlers, Memories, p.196.

${ }^{71}$ AJHR, 1876, G-9, p.23. Atholl Anderson notes that 'Howell's formal household was hardly typical of those in which most of the first few generations of mixed-race children grew up'. Anderson, Race Against Time, p.27. 
${ }^{72}$ Sheila Natusch, Stewart Island historical research papers, 1840-1976, MS-1142, HC.

${ }^{73}$ Wilson, Hakoro Ki Te Iwi, p.33.

${ }^{74}$ ibid., pp.66-67; Case files - Addenda [Caroline Howell, Port William, Stewart Island, Eyre Mountain]; Probate for HOWELL Caroline - Riverton - Widow, 1899, DAFG 9066 D328 Box 11 908, (ANZ-D); and Probate for HOWELL Caroline.

${ }^{75}$ Photo E6361, HC. John Broughton and Matapura Ellison, 'Parata, Tame Haereroa', The Dictionary of New Zealand Biography, Volume Two: 1870-1900, Wellington, 1993, pp.373-2. 